\title{
IMPLEMENTASI KEBIJAKAN RENCANA TATA RUANG WILAYAH TAHUN 2012-2032 DI KOTA BENGKULU
}

\author{
Oleh: \\ NOVLIZA EKA PATRISIA, EVA OKTARIANTI \\ Program Studi Ilmu Administrasi Negara Fakultas Ilmu Sosial dan Ilmu Politik \\ Universitas Muhammadiyah Bengkulu
}

\begin{abstract}
Implementation of spatial policy Bengkulu happened complex problems such as conflicts occur land, water shortages and land conversion. This research uses descriptive qualitative research approach. As the results show that: 1. Product policy Local Regulation number 14 in 2012 on Bengkulu Spatial Planning is good 2. Implementation of spatial policy Bengkulu is well enough but there are still some discrepancies that occur in the implementation. In the application of the Sustainable Urban Development concept is appropriate but the environmental issues become crucial issues encountered in the implementation of spatial policy in realizing about Sustainable Urban Development 3. The factors enabling in the implementation of spatial policy in Bengkulu are policy on Bengkulu spatial planning, socialization, liveliness implementor. While the factors inhibiting in this research are public awareness and land conversion.
\end{abstract}

Keywords: spatial decentralization, policy implementation, sustainable urban development

\section{PENDAHULUAN}

Pembangunan nasional adalah rangkaian upaya pembangunan yang berkesinambungan yang meliputi seluruh aspek kehidupan masyarakat, bangsa dan negara, untuk, untuk melaksanakan tugas mewujudkan tujuan nasional sebagaimana dirumuskan dalam Pembukaan UndangUndang Dasar Republik Indonesia Tahun 1945. Rangkaian upaya pembangunan tersebut memuat kegiatan pembangunan yang berlangsung tanpa henti, dengan menaikkan tingkat kesejahteraan masyarakat dari generasi ke generasi.

Pembangunan di daerah pada masa reformasi mengalami pergeseran pada kewenangannya. Adapun berdasarkan Undang- Undang No.32 tahun 2004 tentang Pemerintah Daerah pasal 14 ayat 2, urusan wajib yang menjadi kewenangan pemerintahan daerah untuk kabupaten/kota merupakan urusan yang berskala kabupaten/kota adalah kewenangan dalam perencanaan, pemanfaatan, dan pengawasan tata ruang. Pemerintah daerah memiliki kewenangan sendiri dalam urusan otonomi daerah khususnya yaitu dalam perencanaan, pemanfataan, dan pegawasan tata ruang. Pemerintah daerah dapat melakukan kewenangan dalam pembuatan kebijakan tersebut. Pasolong (2008, h. 38-39) secara konseptual kebijakan publik dapat dilihat dari Kamus Administrasi Publik Chandler dan Plano (1988, h.107), mengatakan bahwa kebijakan publik adalah pemanfaatan yang strategis terhadap sumber-sumber daya yang ada.

Seringkali kebijakan yang telah dibuat pemerintah mengalami beberapa hambatan atau kurang berhasil pada tahap implementasi kebijakan itu sendiri. Namun dalam implementasi kebijakan tersebut harapan dari pemerintah dan juga lapisan masyarakat sebenarnya adalah 
dapat terwujudnya pembangunan yang berkelanjutan dari berbagai kebijakan yang telah dilakukan. Seiring dengan konsep pembangunan berkelanjutan yang telah dilaksanakan pemerintah, yang melalui sidang umum PBB tahun 1987 disepakati sebagai asas bersama seluruh negara di dunia sekaligus menjadi pedoman pemerintah Indonesia. Namun seiring berjalannya waktu pembangunan seringkali memiliki masalah yang kompleks dan berdampak pada lingkungan. Selanjutnya melalui KTT Bumi di Rio de Janeiro 1992 asas dan konsep tersebut dituangkan dalam program dunia disebut Agenda 21. Namun pada perkembangan pembangunan kota berkelanjutan lebih berkembang lagi yaitu menurut Budihardjo (2005, h.27) menjelaskan untuk menciptakan kota yang berkelanjutan diperlukan lima prinsip dasar yang dikenal dengan Panca E: Environment (Ecologi), Economy (Employment), Equity Engagement, dan Energy, (Reseaarch Triangle Institute, 1996).

Pada saat ini masalah lingkungan menjadi masalah krusial yang pada intinya berpengaruh terhadap pembangunan kota berkelanjutan. Ketika ketidakseimbangan lingkungan terjadi maka dapat mempengaruhi proses implementasi kebijakan yang dilakukan. Di Kota Bengkulu kebijakan tata ruang wilayah tercantum dalam Peraturan Daerah No. 14 tahun 2012 tentang Rencana Tata Ruang Wilayah Kota Bengkulu Implementasi kebijakan tata ruang wilayah di Kota Bengkulu seringkali menemui baberapa permasalahan. Permasalahan tersebut antara lain terjadinya konflik pemanfaatan ruang, Permasalahan yang terjadi lainnya adalah terjadinya defisit air yang disebabkan karena hutan kurang memenuhi standar.

Kawasan hutan di Kota Bengkulu meliputi hutan negara dan hutan rakyat dengan tercantum dalam Undang-undang
No. 26 tahun 2007 tentang Penataan Ruang dan wilayah dengan luas areal mencapai 9.482 ha. Luas kawasan hutan ini hanya mencapai $13,76 \%$ sehingga jauh dari standar yang disyaratkan sebanyak $30 \%$. Selain itu alih fungsi lahan sering dijumpai. Di dalam permukiman di pinggiran kota tampak ditemui petakpetak kebun yang berselang-seling dengan perumahan penduduk. Selain itu pada areal hutan yang secara keruangan cenderung lebih berfungsi "lindung" juga terdapat pemanfaatan lain yang bersifat budidaya seperti perkebunan maupun pertanian rakyat. Dari pemaparan masalah di atas tergambar jelas bahwa permasalahan implementasi kebijakan tata ruang wilayah sangat kompleks maka pemerintah Kota Bengkulu berupaya untuk menerapkan konsep pembangunan kota berkelanjutan dalam implementasi kebijakan tata ruang wilayah.

Penelitian ini bertujuan mengetahui, mendeskripsikan dan menganalisis produk kebijakan Peraturan Daerah No. 14 tahun 2012 tentang Rencana Tata Ruang Wilayah Kota Bengkulu berdasarkan Desentralisasi Spasial, implementasi kebijakan tata ruang wilayah dalam mewujudkan pembangunan kota berkelanjutan serta faktor pendukung dan penghambat dalam implementasi kebijakan tata ruang wilayah dalam mewujudkan pembangunan kota berkelanjutan di Kota Bengkulu.

\section{TINJAUAN PUSTAKA}

\section{Kebijakan Publik dan Model Implementasi Kebijakan Publik}

Menurut Thomas R. Dye yang dikutip oleh Syafii (2006, h.105) kebijakan publik adalah apa pun juga yang dipilih pemerintah, apakah mengerjakan sesuatu atau tidak mengerjakan sesuatu (mendiamkan) sesuatu itu (whatever government choose to do or not to do). Model implementasi kebijakan yang dikembangkan oleh George C. Edward III dinamakan 
Direct and Indirect Im pact on Implementation. Dalam pendekatan yang diteorimakan oleh Edward III, terdapat empat variable yang sangat menentukan keberhasilan implementasi suatu kebijakan yang dikutip oleh Agustino (2008, h.149) yaitu komunikasi, sumber daya, disposisi dan struktur birokrasi.

\section{Otonomi Daerah}

Dalam Undang-Undang Nomor 32 tahun 2004 tentang Pemerintahan Daerah, prinsip otonomi daerah menggunakan prinsip otonomi seluas-luasnya, dalam arti daerah diberikan kewenangan mengurus dan mengatur semua urusan pemerintah di luar yang menjadi urusan pemerintah yang ditetapkan dalam Undang- Undang ini. Daerah memiliki kewe-nangan membuat kebijakan daerah untuk memeberi pelayanan, peningkatan peran serta, prakarsa, dan pemberdayaan masyarakat yang bertujuan pada peningkatan kesejahteraan rakyat. Sejalan dengan prinsip tersebut dilak-sanakan pula prinsip otonomi nyata dan bertanggung jawab. Prinsip otonomi nyata adalah suatu prinsip bahwa untuk menangani urusan pemerintahan dilaksanakan berdasarkan tugas, wewenang, dan kewajiban yang senyatanya telah ada dan berpotensi untuk tumbuh, hidup dan berkembang sesuai dengan potensi dan kekhasan daerah (Kaloh (2007, h. 72-73)).

\section{Desentralisasi Spasial}

Smith (1985, h.8-12) yang dikutip oleh Muluk (2006, h.8) mengungkapkan bahwa desentralisasi mencakup beberapa elemen yakni:

1) Desentralisasi memerlukan pembatasan area, yang bisa didasarkan pada tiga hal (pola spasial kehidupan sosial dan ekonomi, rasa identitas politik, dan efisiensi pelayanan publik yang bisa dilaksanakan).

2) Desentralisasi yang meliputi pula pelendegasian wewenang, baik itu wewenang politik maupun kewenangan birokratis. Pemerintah
Daerah memiliki kewenangannya sendiri dalam desentralisasi spatial. Hal ini dipertegas dalam Undangundang No.32 tahun 2004 tentang Pemerintah Daerah pasal 14 yaitu: urusan wajib yang menjadi kewenangan pemerintahan daerah untuk kabupaten/kota merupakan urusan yang berskala kabupaten/kota meliputi:

a) Perencanaan dan pengendalian pembangunan;

b) Perencanaan, pemanfaatan, dan pengawasan tata ruang;

c) Penyelenggaraan ketertiban umum dan ketentraman masyarakat;

d) Penyediaan sarana dan prasarana umum;

e) Penanganan bidang kesehatan;

f) Penyelenggaraan pendidikan;

g) Penanggulangan masalah sosial;

h) Pelayanan bidang ketenagakerjaan;

i) Fasilitasi pengembangan koperasi, usaha kecil dan menengah;

j) Pengendalian lingkungan hidup;

k) Pelayanan pertanahan;

1) Pelayanan kependudukan, dan catatan sipil;

m)Pelayanan administrasi umum pemerintah- an;

n) Pelayanan administrasi penanaman modal;

o) Penyelenggaraan pelayanan dasar lainnya;

p) Urusan wajib lainnya yang diamanatkan oleh peraturan perundang-undangan.

\section{Perencanaan Tata Ruang Wilayah}

Menurut Conyer \& Hills (1994) yang dikutip oleh Tarigan (2004, h.4) perencanaan adalah suatu proses yang berkesinambungan yang mencakup keputusan-keputusan atau pilihan-pilhan berbagai alternatif penggunaan sumber daya untuk mencapai tujuan-tujuan tertentu pada masa yang akan datang.

Direktorat Bina Tata Perkotaan dan 
Pedesaan Ditjen Cipta Karya Dep. PU (1996) yang dikutip oleh Tarigan ( 2004, h.43) memberikan definisi tentang ruang sebagai berikut: "Ruang adalah wadah yang meliputi ruang daratan, ruang lautan, dan ruang udara, termasuk di dalamnya lahan atau tanah, air, udara dan benda lainnya serta daya dan keadaan, sebagai satu kesatuan wilayah tempat manusia dan makhluk lainnya hidup dan melakukan kegiatan serta memelihara kelangsungan hidupnya."

\section{Pembangunan Kota Berkelanjutan}

Secara umum konsep pembangunan kota berkelanjutan didefinisikan sebagai pembangunan kota yang mengedepankan adanya keseimbangan antara aspek ekonomi, sosial- budaya dan lingkungan hidup. Keseimbangan ini penting untuk menjamin adanya keberlanjutan dalam pemanfaatan sumber daya alam yang tersedia, tanpa mengurangi peluang generasi yang akan datang untuk menikmati kondisi yang sama. Budihardjo (2005, h.27) menjelaskan untuk menciptakan kota yang berkelanjutan diper- lukan lima prinsip dasar yang dikenal dengan Panca E: Environment (Ecologi), Economy (Employment), Eqiuty Engagement, dan Energy, (Reseaarch Triangle Institute, 1996). Budihardjo (2005, h.29) Kota yang berkelanjutan mesti memiliki ekonomi yang kuat, lingkungan yang serasi, tingkat sosial yang relatif setara penuh keadilan, kadar peran serta masyarakat yang tinggi, dan konservasi energi yang terkendali dengan baik.

\section{METODE PENELITIAN}

Penelitian ini menggunakan
metode penelitian pendekatan deskripstif. Bogdan dan Taylor (1975, h.5) yang dikutip oleh Moleong (2000, h.3) mendefinisikan metodologi kualitatif sebagai prosedur penelitian yang menghasilkan data deskriptif berupa kata-kata tertulis atau lisan dari orang-orang dan perilaku yang dapat diamati. Pendekatan ini diarahkan pada latar dan individu tersebut secara holistik (utuh). Pendekatan dalam penelitian ini adalah pendekatan deskriptif dirancang untuk mengumpulkan informasi tentang keadaan-keadaan nyata sekarang. Jadi penelitian kualitatif dengan pendekatan deskriptif adalah penelitian yang mengungkapkan fakta apa adanya tentang suatu objek, gejala, keadaan dengan menggambarkan, menguraikan, menginterpretasikan, dan diambil suatu kesimpulan dalam bentuk tulisan yang sistematis. Fokus dalam penelitian ini adalah sebagai berikut:

1. Produk Kebijakan Peraturan Daerah No.14 tahun 2012 tentang Rencana Tata Ruang Wilayah Kota Bengkulu berdasarkan Desentralisasi Spasial

2. Implementasi Kebijakan Tata Ruang Wilayah Dalam Mewujudkan Pembangunan Kota Berkelanjutan

3. Faktor-faktor pendukung dan penghambat dalam implementasi kebijakan tata ruang wilayah dalam mewujudkan pembangunan kota berkelanjutan di kota Bengkulu.

\section{HASIL PENELITIAN DAN PEMBAHASAN}

Produk Kebijakan Peraturan Daerah No.14 tahun 2012 tentang Rencana Tata Ruang Wilayah Kota Bengkulu berdasarkan Desentralisasi Spasial

Produk kebijakan tata ruang wilayah Kota Bengkulu yang tertuang dalam Peraturan Daerah No. 14 tahun 2012 tentang Rencana Tata Ruang Wilayah Kota Bengkulu sudah baik. Peraturan Daerah No. 14 tahun 2012 tentang Rencana Tata Ruang Wilayah Kota Bengkulu memberikan arahan yang baik dan sudah disusun secara sistematis.

\section{Implementasi Kebijakan Tata Ruang Wilayah Dalam Mewujudkan Pembangunan Kota Berkelanjutan}
A. Analisis Kesesuaian Rencana Tata Ruang
Wilayah
dengan 


\section{Implementasinya}

Berdasarkan hasil penelitian analisis implementasi menggunakan model imple- mentasi George Edward III yang dikutip oleh Agustino (2008, h.149-153) yaitu sebagai berikut:

\section{1) Komunikasi}

Komunikasi dilakukan oleh Badan Perencanaan Pembangunan Kota Bengkulu, Dinas Pekerjaan Umum dan Badan Lingkungan Hidup Kota Bengkulu sudah baik. Namun masih sering terjadi miskomunikasi dengan masyarakat dalam implemntasi kebijakan tata ruang wilayah Kota Bengkulu.

2) Sumber Daya

Sumber daya dalam implementasi kebijakan tata ruang wilayah terdiri dari Sumber daya pendukung dari pemerintah daerah yaitu Badan Perencanaan Pembangunan Kota Bengkulu, Dinas Pekerjaan Umum dan Badan Lingkungan Hidup sudah baik. Sumber daya pendukung lainnya adalah pendanaan yang sudah mencukupi.

\section{3) Disposisi}

Disposisi atau sikap positif antar implementor kebijakan tata ruang wilayah sudah menunjukan sikap positif yang baik.

\section{4) Struktur Birokrasi}

Struktur birokrasi dalam implementasi kebijakan tata ruang wilayah sudah jelas. Badan Perencanaan Pembangunan Kota Bengkulu sebagai pengatur kebijakan, Dinas Pekerjaan Umum Kota Bengkulu memiliki kejelasan struktur sebagai pelaksana teknis di lapangan bersama dengan Badan Lingkungan Hidup yang fokus terhadap implementasi kebijakan tata ruang dalam membangun kesinambungan lingkungan yang kondusif.

Namun analisis kesesuaian rencana tata ruang wilayah Kota Bengkulu dengan implementasinya diwarnai dengan ketidaksesuaian. Ketidaksesuaian tersebut adalah sebagai berikut:

a) Konflik lahan yang banyak melibatkan masyarakat dengan pemerintah atau pihak swasta.

b) Defisit air di Kota Bengkulu

c) Alih fungsi lahan pertanian ke non- pertanian yang banyak terjadi di Kota Bengkulu.

d) Konversi kawasan lindung untuk kawasan budidaya dan wisata.

B. Penempatan Wilayah Strategis Kota Bengkulu ditinjau dari kawasan strategis pertumbuhan ekonomi, sosial budaya dan lingkungan berdasarkan Peraturan Daerah No. 14 tahun 2012 tentang Rencana Tata Ruang Wilayah Kota Bengkulu

Secara umum berdasarkan hasil penelitian pemerintah daerah Kota Bengkulu sudah tepat dalam menempatkan wilayah strategis yang meliputi kawasan strategis ekonomi, kawasan strategis sosial budaya dan kawasan strategis daya dukung lingkungan. Kawasan strategis tersebut sudah tertuang dalam Peraturan Daerah No.14 tahun 2012 tentang Rencana Tata Ruang Wilayah Kota Bengkulu.

\section{Pengendalian Pemanfaatan Tata Ruang Wilayah Kota Bengkulu berdasarkan Peraturan Daerah No. 14 tahun 2012}

Pengendalian pemanfataan tata ruang wilayah Kota Bengkulu sudah dilaksanakan oleh pemerintah daerah Kota Bengkulu. Pemerintah daerah Kota Bengkulu dalam melakukan pengendalian pemanfaatan tata ruang wilayah Kota Bengkulu dengan melalui:
1)
Ketentuan umum peraturan zonasi 
2) Ketentuan Perizinan

3) Ketentuan pemberian insentif dan di- sinsetif,dan

4) Arahan pengenaan sanksi.

Namun praktek di lapangan saat ini masih ada beberapa masalah yang sering terjadi. Masalah yang sering kali muncul adalah maslah perizinan. Banyak terjadi di lapangan, ada bangunan terbangun yang belum sesuai dengan kebijakan tata ruang wilayah. Selain itu, tempat terbangun yang belum memiliki izin mendirikan bangunan. Masalah-masalah tersebut diperparah lagi dengan alih fungsi lahan yang semakin merebak di Kota Bengkulu.

\section{Penerapan Konsep Pembangunan Kota Berkelanjutan dalam Implementasi Kebijakan Tata Ruang Wilayah Kota Bengkulu}

Berdasarkan hasil penelitian penerapan konsep Pembangunan Kota Berkelanjutan dalam Implementasi Kebijakan Tata Ruang Wilayah Kota Bengkulu adalah sebagai berikut:

\section{1) Ekonomi}

Penerapan konsep pembangunan kota berkelanjutan ditinjau dari aspek ekonomi di Kota Bengkulu telah mampu dilakukan dengan baik. Hal ini terlihat dengan keadaan ekonomi yang kondusif dan berkelanjutan. Ekonomi di Kota Bengkulu telah mampu menggambarkan pertumbuhan yang signifikan sehingga mampu memberikan keberlanjutan ekonomi.

\section{2) Ekologi (Lingkungan)}

Penerapan konsep pembangunan kota berkelanjutan dalam aspek ekologi (lingkungan) di Kota Bengkulu kurang optimal. Masalah yang masih dihadapi adalah masalah sampah. Sampah ini banyak berseliweran di dalam Kota khususnya jalan-jalan protokal kota.
Selain itu masalah lingkungan lainnya yaitu alih fungsi lahan pertanian ke non-pertanian dan masalah konversi kawasan lindung untuk budidaya masih banyak dijumpai.

\section{3) Equity (Pemerataan)}

Equity (pemerataan) di Kota Bengkulu telah dilakukan dengan baik Hal ini terlihat dengan tidak adanya disparitas yang terjadi antar kecamatan. Dapat dilihat secara keseluruhan bahwa pertumbuhan ekonomi antara pusat kota dan kecamatan-kecamatan lain di Kota Bengkulu menunjukan keunikan yaitu dapat tumbuh beberengan.

4) Engagement (Peran Serta)

Peran serta yang ditunjukan oleh pemerintah daerah sudah baik namun peran serta masyarakat pengguna ruang kurang baik karena masyarakat masih banyak yang menyalahi penggunaan ruang di Kota Bengkulu.

\section{5) Energi}

Energi di Kota Bengkulu sudah cukup bagus. Salah satu program yang dikembangkan oleh Pemerintah Kota Bengkulu adalah energi biogas yang berasal dari kotoran ternak. Dengan program ini maka energi biogas dapat meningkatkan energi di Kota Bengkulu. Namun dalam pengembangannya masih perlu pihak lain untuk mengembangkan program ini sekaligus untuk menerapkan konsep pembangunan kota berkelanjutan pada aspek energi dengan berkelanjutan.

\section{Faktor-faktor pendukung dan penghambat dalam implementasi kebijakan tata ruang wilayah dalam mewujudkan pembangunan kota berkelanjutan di Kota Bengkulu}

\section{A. Faktor Pendukung}

Faktor pendukung berdasarkan hasil penelitian ini adalah sebagai 
berikut:

1) Kebijakan yang ditetapkan oleh pemerintah daerah Kota Bengkulu tentang arahan dalam pengaturan tata ruang wilayah

2) Sosialisasi,

3) Keaktifan implementor

\section{B. Faktor Penghambat}

Faktor penghambat yang diperoleh dari penelitian ini adalah sebagai berikut:

1) Kesadaran masyarakat

2) Alih fungsi lahan

\section{PENUTUP}

\section{Kesimpulan}

Berdasarkan hasil penelitian, maka dapat disimpulkan sebagai berikut:

1. Produk kebijakan Peraturan Daerah No. 14 tahun 2012 tentang Rencana Tata Ruang Wilayah Kota Bengkulu sudah baik dan disusun secara sistematis.

2. Analisis kesesuaian rencana tata ruang wilayah Kota Bengkulu dengan implementasinya diwarnai dengan ketidaksesuaian. Ketidaksesuaian itu lebih mengarah pada alih fungsi lahan, konflik lahan dan defisit air.

3. Penempatan Kawasan strategis ekonomi, kawasan strategis sosial budaya dan kawasan strategis kepentingan fungsi dan daya dukung lingkungan secara umum telah sesuai dengan arahan Paraturan Daerah No.14 tahun 2012 tentang Rencana Tata Ruang Wilayah Kota Bengkulu.

\section{Pengendalian Pemanfaatan tata} Ruang Wilayah Kota Bengkulu sudah berdasarkan Paraturan Daerah No.14 tahun 2012 tentang Rencana Tata Ruang Wilayah Kota Bengkulu. Namun dalam prakteknya masih dijumpai beberapa alih fungsi lahan.

5. Penerapan konsep pembangunan kota berkelanjutan sudah diterapkan di Kota Bengkulu. Namun masalah lingkungan merupakan aspek yang hingga saat ini masih memerlukan perhatian.

6. Faktor pendukung dan penghambat yakni kesadaran masyarakat dan alih fungsi lahan.

\section{SARAN}

Berdasarkan hasil penelitian, maka saran dari penelitian ini adalah sebagai berikut:

1. Diharapkan adanya sinergitas yang baik antar implementor dalam implementasi kebijakan tata ruang wilayah ini. Karena kerjasama antara pemerintah daerah masih sering terjadi misscomunication.

2. Diharapkan pemerintah daerah Kota Bengkulu menghukum secara tegas bagi pelanggar yang tidak mematuhi Peraturan Peraturan Daerah No. 14 Tahun 2012 tentang Rencana Tata Ruang Wilayah Kota Bengkulu

3. Pemerintah daerah Kota Bengkulu diharapkan selalu gencar menggaungkan sosialisasi mengenai Peraturan Daerah No. 14 Tahun 2012 tentang Rencana Tata Ruang Wilayah Kota Bengkulu. Karena tergolong peraturan daerah yang baru berjalan.

4. Diharapkan masyarakat lebih sadar akan pentingnya mematuhi Peraturan Daerah No. 14 tahun 2012 tentang Rencana Tata Ruang Wilayah Kota Bengkulu, karena kesadaran terhadap lingkungan masih sangat kurang.

\section{DAFTAR PUSTAKA}

Agustino, Leo. 2008. Dasar-Dasar Kebijakan Publik. Bandung, Alfabeta
Badan Lingkungan Hidup Kota Bengkulu. 2011. Kajian Lingkungan Hidup Strategis. Bengkulu.

Badan Perencanaan Pembangunan Kota Bengkulu. 2013. Produk Domestik Regional Bruto (PDRB) Kota Bengkulu 20082012. Bengkulu. 
Budiharjo, Eko dan Djoko Sujarto. 2005 Kota Berkelanjutan. Bandung, Alumni.

Kaloh. 2007. Mencari Bentuk Otonomi Daerah: Suatu Solusi Dalam Menjawab Kebutuhan Lokal dan Tantangan Global. Jakarta, Rineka Cipta.

Moleong. 2000. Metodologi Penelitian Kualitatif. Bandung, Remaja Rosdakarya.

Muluk, Khairul. 2006. Desentralisasi dan Pemerintahan Daerah. Malang: Banyumedia.

Pasolong, Harbani. 2008. Teori Administrasi Publik. Bandung, Alfabeta.

Peraturan Daerah Nomor 14 Tahun 2012
Tentang Rencana Tata Ruang Wilayah Kota Bengkulu, Badan Perencanaan Pembangunan Kota Bengkulu.

Syafii, Inu Kencana..2006. Ilmu Administrasi Publik (edisi revisi). Jakarta, Rineka Cipta.

Tarigan, Robinson. 2004 Perencanaan Pembangunan Wilayah. Jakarta, Bumi Aksara.

Undang-Undang Nomor 32 Tahun 2004 Tentang Pemerintahan Daerah. Jakarta, Direktorat Otoda 